Received: 13 May 2021

Accepted: 31 August 2021

Online: 07 September 2021

Authors:

P. R. Patel $₫$, Manish Sharma, M. P. Patel Pulses Research Station, S. D. Agricultural University, S. K. Nagar-385506, Gujarat India

$\bigotimes$ prpatel@sdau.edu.in

Emer Life Sci Res (2021) 7(2): 1-4

E-ISSN: 2395-6658

P-ISSN: 2395-664X

DOI: https://doi.org/10.31783/elsr.2021.720104
Research Article

\section{Study of heritability, genetic advancement, variability and character association for yield contributing characters in pigeon pea [Cajanus cajan (L.) Millspaugh]}

\author{
P. R. Patel, Manish Sharma, M. P. Patel
}

\begin{abstract}
Genetic parameters for yield and its attributes in pigeon pea were estimated in a trial conducted during Kharif 2019 with 23 genotypes of pigeon pea. Genotypes were obtained from S.D.A.U., Sardarkrushinagar, JAU, Junagadh, NAU, Navsari and AAU, Vadodara for evaluation of nine characters related to yield. Low, moderate, and high genotypic and phenotypic coefficients of variations were observed. High genotypic and phenotypic coefficients of variations were expressed by seed yield $\mathrm{kg} / \mathrm{ha}$, the number of seeds per pod, pod length, and the number of pods per plant. High heritability coupled with high genetic advancement was observed in the traits such as days to flowering, the number of seeds per pod, pod length, seed yield $\mathrm{kg} / \mathrm{ha}$, test weight, and plant height. Based on the obtained results, the selection may be effective for these variable characters. Character association for studied traits indicated that the number of pods per plant, days to flowering, and days to maturity are strongly associated with the seed yield. Hence, due emphasis should be given to the number of pods per plant for the improvement of seed yield in pigeon pea.
\end{abstract}

Keywords genetic advancement, heritability, pigeonpea, variability

\section{Introduction}

Pigeon pea [Cajanus cajan (L.) Millsp.] $(2 \mathrm{n}=22)$ is a highly important pulse crop containing $21 \%$ protein. It is extensively grown in the semi-arid tropics, and India accounts for $70 \%$ production and $74 \%$ area of the world in pigeon pea production. Although India is ahead ofs the world both in the area and production of pigeon pea, its productivity is lesser than the world's average productivity. Therefore, there is a requirement to enhance the pigeon pea yield by developing high-yielding varieties employing the variability present in the population for yield and its component traits. Therefore, the present study aimed to evaluate the nature and magnitude of genetic variability present in different genotypes of pigeon pea. Little information is available on character association in pigeon pea. The genetic diversity of any given crop species is necessary for the improvement of the crop because it is the guide for the selection of parental lines and breeding design. In the present research, we determined the components of variance and genetic parameters for quantitative characters in pigeon pea genotypes for the improvement of yield and tried to find out the association between the yield and the yield attributing characters of pigeon pea. Correlation analysis thus helps in identifying suitable selection criteria for improving the yield. 
Table 1. Analysis of varience for nine quantitative characters in 23 genotypes of pigeon pea

\begin{tabular}{|c|c|c|c|c|c|c|c|c|c|}
\hline Characters & DF & DM & PH & BP & PP & PL & SP & TW & SY \\
\hline $\begin{array}{l}\text { Replication } \\
(\mathrm{df}=2)\end{array}$ & 1.449 & $20.188 * *$ & 13.318 & 5.264 & 238.179 & $0.638 *$ & 0.14 & 0.097 & 98105.913 \\
\hline $\begin{array}{l}\text { Treatments } \\
(\mathrm{df}=22)\end{array}$ & $\begin{array}{l}99.776 * \\
*\end{array}$ & 78.383 ** & $977.857 * *$ & $3.763^{*}$ & $\begin{array}{c}1050.564 * \\
*\end{array}$ & $1.202 * *$ & $0.999 * *$ & $2.486 * *$ & $\begin{array}{c}411794.110 * \\
*\end{array}$ \\
\hline $\begin{array}{l}\text { Error } \\
(\mathrm{df}=44)\end{array}$ & 1.615 & 2.067 & 156.788 & 1.82 & 416.779 & 0.145 & 0.082 & 0.246 & 52782.094 \\
\hline
\end{tabular}

*Significant at $0.05 \%$ level of probability ** Significance at $0.01 \%$ level of probability Traits DF (Days to flowering), DM (Days to maturity), PH (Plant height), BP (Branches per plant), PP (Pods per plant), Pl (pod length), SP (Seeds per pod),

TW (Test weight), SY (seed yield).

\section{Methodology}

The experiment for the present study was conducted during Kharif, 2019 at Pulses Research Station, S. D. Agricultural University, Sardarkrushinagar. The experimental material comprised of 23 genotypes of pigeon pea. The experiment was laid with 6 rows of each genotype having 4 meters of row length. The spacing adapted between rows to rows was 90 centimeters and between plants to plants was 20 centimeters. For getting a good crop, recommended package of practices was used. In each genotype, five plants were selected randomly for each replication and the following nine quantitative characters viz., days to 50 percent flowering, days to maturity, plant height $(\mathrm{cm})$, number of branches per plant, pods per plant, pod length $(\mathrm{cm})$, seeds per pod, pod length $(\mathrm{cm})$, seeds per pod, 100-seed weight $(\mathrm{g})$, and seed yield $(\mathrm{kg} / \mathrm{ha})$ were observed for estimating the genetic variability. Standard statistical procedures were used for the analysis of variance, genotypic and phenotypic coefficients of variation [1], heritability [2], genetic advancement, and correlation [3].

\section{Results and Discussion}

Genetic variability is the essential requirement of any crop breeding program to grow better cultivars. The objective of this study was to estimate the genetic variability and find out the correlation among the different quantitative traits of pigeon pea. In the present investigation, analysis of variance revealed highly significant differences among the genotypes for all the studied characters (Table 1). The genetic parameters such as the genotypic and phenotypic coefficient of variation (GCV and PCV), heritability, and genetic advance as percent of the mean are also presented in Table 2 .

Table 2. Estimation of components of variance and genetic parameters for nine quantitative characters in

Pigeon pea genotypes

\begin{tabular}{|l|l|l|l|l|l|l|l|l|l|}
\hline SN. & Characters & Vg & Vp & ECV\% & PCV \% & GCV\% & $\begin{array}{l}\text { H2 }(\mathbf{b s}) \\
(\%)\end{array}$ & $\begin{array}{l}\text { GA } \\
\text { GA as } \\
\text { of } \\
\text { mean }\end{array}$ \\
\hline 1 & $\begin{array}{l}\text { Days to } \\
\text { flowering }\end{array}$ & 37.72 & 34.33 & 1.21 & 5.59 & 5.45 & 95.29 & 10.97 & 11.50 \\
\hline 2 & $\begin{array}{l}\text { Days to } \\
\text { maturity }\end{array}$ & 25.43 & 27.50 & 0.93 & 3.39 & 3.26 & 92.48 & 6.45 & 9.99 \\
\hline 3 & Plant height & 273.68 & 430.47 & 5.81 & 9.62 & 7.67 & 63.58 & 12.59 & 27.16 \\
\hline 4 & $\begin{array}{l}\text { Branches per } \\
\text { plant }\end{array}$ & 0.64 & 2.46 & 13.69 & 15.95 & 8.17 & 26.25 & 8.62 & 0.84 \\
\hline 5 & Pods per plant & 211.26 & 628.04 & 14.05 & 17.24 & 10.00 & 33.64 & 11.94 & 17.36 \\
\hline 6 & Pod length & 0.35 & 0.49 & 7.93 & 14.67 & 12.35 & 70.80 & 21.39 & 1.02 \\
\hline 7 & Seeds per pod & 0.30 & 0.38 & 6.81 & 14.80 & 13.14 & 78.83 & 24.03 & 1.01 \\
\hline 8 & Test weight & 0.74 & 0.99 & 4.25 & 8.53 & 7.39 & 75.16 & 13.20 & 1.54 \\
\hline 9 & $\begin{array}{l}\text { Seed yield } \\
\text { kg/ha }\end{array}$ & 119670.67 & 172452.76 & 8.73 & 15.79 & 13.15 & 69.39 & 22.57 & 593.74 \\
\hline
\end{tabular}


Values of phenotypic coefficient of variation were greater than the genotypic coefficient of variation for all the studied traits (Table 2). It implied that apparent variation was not only due to the differences in the genotypes but also due to the influence of the environment. The values for the phenotypic coefficient of variation obtained for various yield and yield attributing characters ranged from 3.39 to 17.24. The highest PCV was observed for pods per plant (17.24\%) followed by branches per plant (15.95\%), seed yield $\mathrm{kg} / \mathrm{ha}(15.79 \%)$, Seeds per pod $(14.80 \%)$, and pod length $(14.67 \%)$. This indicated high variability for this character among the accessions and hence, there is a great scope for the improvement of these characters by the direct selection among the genotypes. Moderate PCV was observed for plant height (9.62\%) and test weight (8.53\%). The values for the genotypic coefficient of variation obtained for various yield and yield attributing characters ranged from 3.26 to 13.15 percent. The highest GCV was observed for seed yield $\mathrm{kg} / \mathrm{ha}(13.15 \%)$ followed by seeds per pod (13.14\%) and pod length (12.35\%). Moderate GCV was observed for pods per plant (10.00\%), branches per plant $(8.17 \%)$, and plant height $(7.67 \%)$ The variability was mainly due to the genetic constitution. The narrow difference between genotypic and phenotypic coefficients of variation for all the traits indicated a little influence of environment on the expression of these traits. This inferred phenotypic variability was a consistent measure of genotypic variability in this study. The numbers of branches per plant and days to maturity recorded the highest and lowest coefficients of variation among the 9 studied characters, respectively.

Table 3. Correlation coefficients among nine quantitative traits in pigeon pea genotypes

\begin{tabular}{|c|c|c|c|c|c|c|c|c|c|}
\hline & DF & DM & PH & BP & PP & PL & SP & TW & SY \\
\hline DF & 1.000 & & & & & & & & \\
\hline $\mathrm{DM}$ & $0.993 * *$ & 1.000 & & & & & & & \\
\hline $\mathrm{PH}$ & 0.343 & 0.317 & 1.000 & & & & & & \\
\hline BP & -0.271 & -0.149 & $-0.859 * *$ & 1.000 & & & & & \\
\hline$\overline{P P}$ & $0.632 * *$ & $0.619 * *$ & -0.150 & -0.230 & 1.000 & & & & \\
\hline PL & 0.000 & -0.018 & 0.171 & -0.379 & -0.224 & 1.000 & & & \\
\hline SP & -0.028 & -0.043 & 0.289 & $-0.473 *$ & -0.227 & $0.995 * *$ & 1.000 & & \\
\hline TW & 0.223 & 0.143 & 0.044 & -0.316 & -0.329 & $0.583 * *$ & $0.430^{*}$ & 1.000 & \\
\hline SY & $1.000 * *$ & $1.00 * *$ & $-37.921 * *$ & $-25.239 * *$ & $1.000 * *$ & $-101.832 * *$ & $-61.597 * *$ & $-59.606 * *$ & 1.000 \\
\hline
\end{tabular}

The highest PCV and GCV were recorded for seed yield $\mathrm{kg} / \mathrm{ha}$, seeds per pod, pod length, pods per plant, and branches per plant. The genotypic and phenotypic coefficients of variation indicated the extent of variability for different traits. Similar results were reported by many researchers [4-7] for the number of pods per plant.

The efficacy of selection not only relies on the magnitude of genetic variability but also on the heritability of the desirable traits. High heritability was obtained for all the studied traits. While heritability is also influenced by the environment, therefore only heritability may not help in the selection of genotype for specific characters. However, the heritability estimates in conjunction with the predicted genetic advancement can be more consistent [3].

Genetic advance as percent of mean ranged from 0.84 to 593.74. Seed yield $\mathrm{kg} / \mathrm{ha}$ (593.74)

recorded the highest genetic advance as percent of mean followed by plant height (27.16), pods per plant (17.36), and days to flowering (11.50).

High heritability linked with high genetic advance indicates the predominance of additive gene effects and the effectiveness of selection for that trait. High heritability along with high genetic advance as percent of mean was recorded for seed yield $\mathrm{kg} / \mathrm{ha}$, plant height, days to flowering, and days to maturity. A 
similar observation was reported by Ram et al., [8] for the number of branches per plant, the number of pods per plant, and seed yield per plant. Thus, traits governed by additive gene action are likely to accumulate more additive genes leading to further improvement of their performance by selection.

The correlation coefficient for different quantitative characters are presented in Table 3. Seed yield $\mathrm{kg} / \mathrm{ha}$ was highly significant and positively correlated with the number of pods per plant, days to flowering, and days to maturity. However plant height, branches per plant, pod length, seeds per pod, and test weight were non significantly correlated with seed yield. Regarding inter-correlation, days to flowering had a positive significant correlation with days to maturity and pods per plant. Days to maturity had a positive significant correlation with pods per plant. Seeds per pod and test weight had a significant positive correlation with pod length, whereas seeds per pod had a positive significant correlation with test weight (Table 3). Consequently, the selection of these traits will be useful for the improvement of yield in pigeon pea. The results were in agreement with Singh [9] and Bainiwal et al., [10].

From the present study, it is inferred that for improving seed yield in pigeon pea due emphasis should be placed on the number of pods per plant which had a positive correlation and had a high direct and indirect effect on seed yield. Hence, seed yield can be improved in pigeon pea through the selection of this character.

\section{References}

[1] G.W. Burton (1952). Quantitative inheritance in grasses. Proc. 6th Int. Grassland Cong., 1: 277-283.

[2] J. L. Lush (1940). Intra - sire correlation and regression of offspring on dams as a method of estimating heritability of characters. J. Anim. Sci., 1940: 293 - 301.

[3] H. W. Johnson, H. F. Robinson and R. E. Comstock (1955). Estimation of genetic variability and environmental variability in soybean. Agron. J., 47: 314 - 318.

[4] D. Bhadru (2008). Genetic variability, heritability and genetic advance in pigeon pea

[Cajanus cajan (L.) Millsp.]. Abs. Res. on Crops., 9: 661- 662.

[5] S. S. Sarsamkar, S. B. Borgaonkar, S.V. Kalyankar, B. P. Kadam and G. R. Kadam (2008). Genetic variability studies in pigeon pea [Cajanus cajan (L.) Millsp.]. Int. J. Plant Sciences, 3: 502-503.

[6] V. Shunyu, H. P. Chaturvedi, S. Changkija and J. Singh (2013). Genetic variability in pigeon pea [Cajanus cajan (L) Millsp.] genotypes of Nagaland. Indian Res. J. Genet. Biotech., 5: 165-171.

[7] C. P. Bal, S. G. Bhave, B. L. Thaware and S. S. Desai (2018). Correlation and path analysis studies in pigeon pea (Cajanus cajan). Global J. Biosci. Techn., 7: 70-73

[8] K. Ram, S. Kanak, T. M. Shrimali and B. Geeta (2016). A study on genetic variability, correlation and path analysis in pigeon pea [Cajanus cajan (L.) Millspaugh]. Int. J. Agri. Sci., 8: 2287- 2289.

[9] J. Singh (1999). Correlation coefficient analysis for seed yield in pigeon pea. Crop Res., 17: 381-385.

[10] C. R. Bainiwal, N. Mehrotra and D. S. Jatasra (1981). Studies on variability and correlation in pigeon pea. Indian J. Agric. Res., 15: 161-165. 